\title{
The terminal balls characteristic of eukaryotic rRNA transcription units in chromatin spreads are rRNA processing complexes
}

\author{
Edward B. Mougey, ${ }^{1}$ Marina O'Reilly, ${ }^{2,3}$ Yvonne Osheim, ${ }^{4}$ Oscar L. Miller Jr., ${ }^{2}$ Ann Beyer, ${ }^{4}$ \\ and Barbara Sollner-Webb ${ }^{1}$ \\ ${ }^{1}$ Department of Biological Chemistry, The Johns Hopkins University, School of Medicine, Baltimore, Maryland 21205 USA; \\ ${ }^{2}$ Department of Biology and ${ }^{4}$ Department of Microbiology, University of Virginia, Charlottesville, Virginia 22908 USA
}

When spread chromatin is visualized by electron microscopy, active rRNA genes have a characteristic Christmas tree appearance: From a DNA "trunk" extend closely packed "branches" of nascent transcripts whose ends are decorated with terminal "balls." These terminal balls have been known for more than two decades, are shown in most biology textbooks, and are reported in hundreds of papers, yet their nature has remained elusive. Here, we show that a rRNA-processing signal in the 5'-external transcribed spacer (ETS) of the Xenopus laevis ribosomal primary transcript forms a large, processing-related complex with factors of the Xenopus oocyte, analogous to $5^{\prime}$ ETS processing complexes found in other vertebrate cell types. Using mutant rRNA genes, we find that the same rRNA residues are required for this biochemically defined complex formation and for terminal ball formation, analyzed electron microscopically after injection of these cloned genes into Xenopus oocytes. This, plus other presented evidence, implies that rRNA terminal balls in Xenopus, and by inference, also in the multitude of other species where they have been observed, are the ultrastructural visualization of an evolutionarily conserved 5' ETS processing complex that forms on the nascent rRNA.

[Key Words: rRNA processing complex; terminal balls; eukaryotic rRNA transcription units; chromatin spreads; X. laevis]

Received February 5, 1993; revised version accepted May 21, 1993.

One of the earliest, yet still highly informative and much used methods of studying eukaryotic gene expression, is by direct electron microscopic visualization of the transcribing chromatin (Miller and Beatty 1969a). This technique of native chromatin visualization (forming socalled Miller spreads) has facilitated numerous advances in the analysis of gene expression. These include (1) the finding that eukaryotic rRNA genes are organized typically in tandem head-to-tail arrays separated by "nontranscribed spacers" (Miller and Beatty 1969a); (2) the demonstration that the polarity of ribosomal transcription is from 18S to 28S (Reeder et al. 1976), (3) the first analyses of the synchrony of rRNA transcriptional turnon during development (McKnight and Miller 1976; Foe 1978; Franke et al. 1979); (4) the first indication of transcription of cloned rRNA genes (Trendelenburg and Gurdon 1978); and (5) the ability to visualize spliceosome complexes on nascent RNA polymerase II-driven transcripts (Osheim et al. 1985; Beyer and Osheim 1988).

${ }^{3}$ Present address: Department of Biology, Johns Hopkins University, Baltimore, Maryland 21218 USA.
Because of their ease of identification, rRNA genes are the most amenable to study in Miller spreads. In the resultant micrographs, the active rRNA-coding regions have a characteristic tree-like appearance, with a DNA "trunk" from which close-packed ribonucleoprotein "branches" of increasing length extend. What distinguishes rRNA transcription units from the multitude of RNA polymerase II-driven transcription units is not only their size and high density of nascent transcripts but also the characteristic presence of a "terminal ball" (also called terminal knob and terminal granule) at the distal ends of the ribosomal transcripts (Miller and Beatty 1969a). Such terminal balls are not typically found at the ends of polymerase II-driven transcripts (e.g., Miller and Bakken 1972; McKnight and Miller 1976). Possibly because of these terminal balls decorating the rRNA branches, active ribosomal genes in such spreads are routinely referred to as "Christmas trees," not merely as "pine trees."

First reported on ribosomal transcripts in amphibians [Xenopus and Triturus (Notophthalmus)], terminal balls have been observed since then on rRNA gene transcripts 
across eukaryotes, in all tissues and organisms examined, including algae (Acetabularia), fungi (Saccharomyces), slime molds (Physarum), higher plants (Zea mays), insects (Drosophila, Dytiscus, Bombyx), birds (quail), and mammals (mouse, rat, hamster, human) (Miller and Beatty 1969a,b; Miller and Bakken 1972; Hamkalo et al. 1973; Spring et al. 1974; Trendelenburg 1974; McKnight et al. 1976; Puvion-Dutilleul et al. 1977a,b; Grainger and Ogle 1978; Jamrich et al. 1979; Greimer and Deltour 1984; Saffer and Miller 1986; Scheer and Benavente 1990). Yet, despite the characteristic presence of the terminal balls reported in well over a hundred papers over the last 23 years (for additional early references, see Franke et al. 1979), their function and biochemical nature are still unknown.

The ubiquitous presence of terminal balls suggests that they represent a feature of ribosomal gene expression that is conserved across eukaryotic evolution. This conservation is especially striking because terminal balls appear to form in the rapidly diverging 5 '-external transcribed spacer (ETS) region of the rRNA. It has been suggested that the terminal balls represent a coiling up of a substantial $5^{\prime}$ portion of the nascent pre-ribosomal ribonucleoprotein (pre-rRNP) (Puvion-Dutilleul et al. 1977b; Franke et al. 1979; Puvion-Dutilleul 1983) or that they may be part of ribosomal particles that are forming on the nascent rRNA (Puvion-Dutilleul 1983; Osheim and Beyer 1985), possibly facilitating the formation and export of the 40S ribosomal subunit to the cytoplasm (Miller and Hamkalo 1982). Other possibilities include their being a remnant of the RNA polymerase I initiation process, components bound to the $5^{\prime}$ polyphosphate group that is retained on the ribosomal primary transcript, or a rRNA processing complex (Reeder et al. 1979; Sollner-Webb and Mougey 1991).

In separate studies, we have identified a processing event that takes place early in the maturation of mouse pre-rRNA and removes the first 650 nucleotides of the primary transcript. This processing is readily reproduced in vitro using mouse cell extracts (Miller and SollnerWebb 1981) and it occurs efficiently in vivo, as $\sim 90 \%$ of mouse pre-rRNA molecules lack the first 650 nucleotides of the primary transcript (Miller and Sollner-Webb 1981; Gurney 1985). A 120-nucleotide region immediately downstream of the processing site directs this processing (Craig et al. 1987, 1991; Fig. 1), and it forms a sizable specific complex that sediments at $\sim 20 \mathrm{~S}$, with a number of distinct polypeptides of the extract (Kass and Sollner-Webb 1990|. This 5' ETS processing also requires the U3 small nuclear ribonucleoprotein (snRNP) (Kass et al. 1990). The mouse processing signal is $\sim 85 \%$ conserved in human and rat pre-rRNA, starting at residues 422 and 793, respectively, as well as in other mammals, and these regions also direct processing (Kass et al. 1987; Stroke and Weiner 1989; Tower et al. 1989). A report that Xenopus oocyte pre-rRNA does not exhibit processing in its 5' ETS (Savino and Gerbi 1991) suggested that this kind of rRNA processing might be limited to mammalian species. However, we found recently that Xenopus laevis pre-rRNA of cultured kidney cells undergoes a $5^{\prime}$

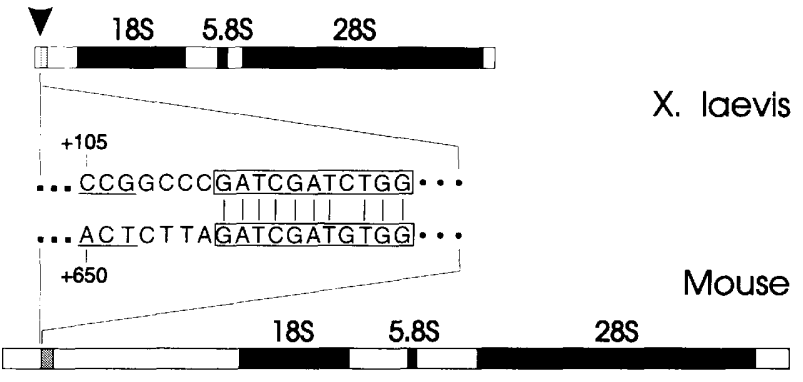

Figure 1. The 5' ETS processing region. The entire $X$. laevis (top) and mouse (bottom) pre-rRNA and expansions of a $5^{\prime}$ portion are represented. The arrowhead indicates the 5' ETS processing site. The stippled boxes (next to arrowheads) denote 120- and 200-nucleotide segments that are conserved in $X$. laevis- $X$. boralis rRNA and in mouse/human/rat/CHO rRNA, respectively; the first 11 nucleotides of these segments are conserved between frog and mammals (boxed residues in the inner diagram; Bourbon et al. 1988). Furlong et al. (1983) noted most of the $X$. laevis/ $X$. borealis conserved sequence. The conserved sequence block in mouse and human rRNA was reported by Kass et al. (1987), whereas that of rat was reported by Bourbon et al. (1988). The processing sites are indicated by the underlining in the middle diagrams to the left of the boxed segment; the $18 \mathrm{~S}$ region starts at residue 714 and 4007 in $X$. laevis and mouse, respectively

ETS processing that is strictly analogous to that of mouse in numerous respects, including in vitro reproduction of this processing both in Xenopus and in mouse cell extracts, the presence of a 120-nucleotide region just downstream from the +105 processing site that is conserved between various Xenopus species (Fig. 1), the association of the processing region with a number of polypeptides of the cell extract to form a specific $\sim 20 \mathrm{~S}$ complex, and a requirement for the U3 snRNP in the processing (Mougey and Sollner-Webb, 1993). The first 11 nucleotides of the Xenopus-conserved signal and the mammalian-conserved signal are the same, and this element is critical both for the frog and for the mouse processing reactions.

In this study we show that the terminal balls characteristic of ribosomal transcription units are the ultrastructural visualization of the 5' ETS rRNA processing complex that we have studied biochemically. To this end, various Xenopus rRNA derivatives have been analyzed for their ability to direct processing and complex formation; parallel constructs were analyzed for terminal ball formation by microinjecting plasmid templates into Xenopus oocyte nuclei and visualizing spreads of the resultant nucleoprotein by electron microscopy. Processing-competent rRNAs are shown to form processing complexes and terminal balls, whereas processing-incompetent RNAs do neither. These parallel data, plus several other observations, indicate that terminal balls represent the processing complex that has been analyzed biochemically. Furthermore, the fact that terminal balls have been seen in rRNA spreads all across eukaryotic species suggests that this $5^{\prime}$ ETS processing complex for- 
mation has a conserved and evolutionarily advantageous function.

\section{Results}

The visualization of terminal balls in electron microscopic spreads of transcribing ribosomal chromatin demonstrates that these structures are large and ubiquitously present at or near the $5^{\prime}$ end of nascent rRNA transcripts throughout eukaryotic species. Although it was initially thought that such 5' ETS processing involving formation of a large complex may be specific to mammals, the recent demonstration of a completely analogous $5^{\prime}$ ETS processing in X. laevis tissue culture cells (Mougey and Sollner-Webb, 1993) raises the possibility that the $5^{\prime}$ ETS-processing complex might be what is visualized as the terminal ball structures. Consistent with this proposal, the in vitro-processing complex is $\sim 20 \mathrm{~S}$, it is located near the $5^{\prime}$ end of the pre-rRNA, and, at least in mouse, the processing complex forms rapidly and remains on the nascent pre-rRNA after cleavage (Kass and Sollner-Webb 1990; Mougey and Sollner-Webb, 1993). In apparent contradiction to this hypothesis, however, $\mathrm{Xe}$ nopus oocytes-which were one of the original cell types in which terminal balls were observed (Miller and Beatty $1969 \mathrm{a}, \mathrm{b})$ - have been reported not to undergo 5' ETS processing (Savino and Gerbi 1991).

To determine whether Xenopus oocytes exhibit $5^{\prime}$ ETS processing, we used S1 nuclease analysis to examine RNA from isolated Xenopus oocyte nuclei for $5^{\prime}$ ends corresponding to the approximately + 105 ETS processing site (Fig. 2A). Such molecules are indeed obtained from these germinal vesicles (lane 3; G.V.), and their $5^{\prime}$ ends map to residues +105 to +107 of the pre-rRNA, the same positions as the processed rRNA in the cultured kidney cells (lanes 1, 2; sequence shown in Fig. 1). In the Xenopus oocyte, however, the abundance of the processed rRNA is low, only $\sim 1 \%$ that of the unprocessed rRNA. We have also been unable to detect 5' ETS processing of in vitro-made rRNA that is added to a homogenate of oocyte nuclei or microinjected into nuclei of intact oocytes (data not shown), whereas extracts of cultured $X$. laevis kidney cells are active for this $5^{\prime}$ ETS processing (Mougey and Sollner-Webb, 1993). Thus, Xenopus oocytes do contain $5^{\prime}$ ETS processing activity, but one of the requisite processing components may be quite limiting. This limiting component could be one that is needed for the formation of the complex on the $5^{\prime}$ ETS processing sequences or it could be one that is necessary for processing but does not stably associate with the substrate rRNA.

Because terminal balls are observed in Xenopus oocytes, both on the nascent pre-rRNAs on the $>10^{6}$ genomic and amplified rRNA genes (Miller and Beatty $1969 \mathrm{a}, \mathrm{b})$ and on the transcripts of microinjected rRNA genes (Trundelenberg and Gurdon 1978; Bakken et al. 1982), the components that form these structures must be rather abundant in the oocyte. We therefore examined whether Xenopus oocytes have an excess of the factors needed to assemble the $5^{\prime}$ ETS complex. This experi-

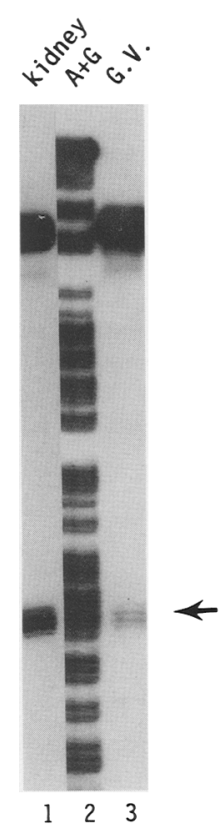

A

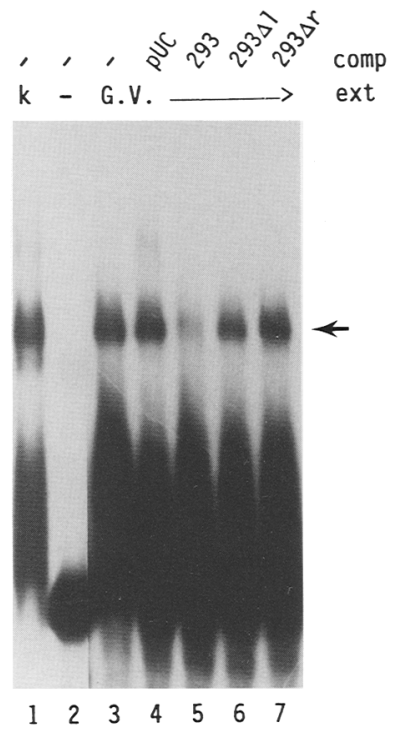

$\begin{array}{llllllllllllllll}1 & 2 & 3 & 4 & 5 & 6 & 7 & 8 & 9 & 10 & 11 & 12 & 13 & 14 & 15 & 16\end{array}$

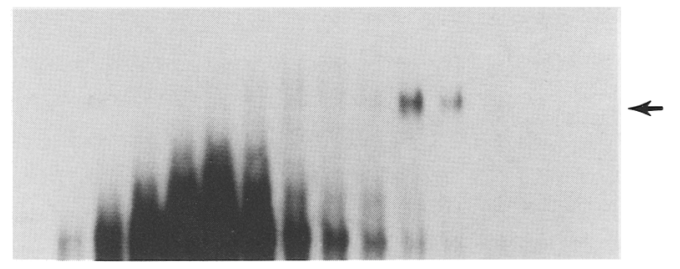

Figure 2. Processing and specific complex formation in the $X$. laevis RNA 5' ETS in oocytes. (A) The $5^{\prime}$ ends of cellular RNA isolated from cultured kidney cells (lane 1) or germinal vesicles [(lane 3); GVs or oocyte nuclei] were mapped by S1 nuclease analysis using a 5 '-end-labeled probe. The dark upper band represents RNA that starts at residue +1 ; the bands indicated by the arrow represent RNAs whose $5^{\prime}$ ends map to residues +105 , +106 , and +107 . Lane 2 is an $A+G$ sequence analysis of the probe DNA (Maxam and Gilbert 1977). (B) X293 RNA (lane 2) was incubated in a reaction with cultured kidney cell extract (lane 1) or with GVs (oocyte nuclei) that had been preincubated with no competitor (lane 3 ) or with the indicated processingcompetent (lane 5) and processing-incompetent (lanes 4, 6, 7) competitor RNAs. The resultant nucleoprotein was resolved by native polyacrylamide gel electrophoresis. The arrow indicates the specific retarded complex. (C) X293 RNA was incubated with oocyte nuclear contents, and the reaction was fractionated by velocity centrifugation. Aliquots of the indicated fraction (lane 1, top of gradient) were analyzed on a nondenaturing polyacrylamide gel. The arrow indicates the specific retarded complex, which comigrates with the complexes in $B$. Sedimentation markers of catalase, thyroglobulin, and 18S and 28S Xenopus rRNA (with $S_{w}^{20}$ values of 11S, 19S, 18S, and $28 \mathrm{~S}$, respectively) were centered in fractions $7,11,11.3$, and 16.8, respectively.

ment (Fig. 2B) used the in vitro transcript $X 293$ RNA that contains $X$. laevis rRNA residues $28-293$ and is processing-competent in the Xenopus kidney cell extract, as 
well as two processing-incompetent derivatives that lack the left and right portions of the essential 11 -nucleotide conserved element of the processing signal, the X2934l and $X 293 \Delta r$ RNAs (see Materials and methods, Fig. 1; Mougey and Sollner-Webb, 1993). In a homogenate of Xenopus oocyte nuclei, processing-competent X293 RNA assembles a slowly migrating complex (Fig. 2B, lane 3; position indicated by the arrow|. Using extracts that were preincubated with unlabeled competitor RNAs, this complex is seen to be specific for the rRNA $5^{\prime}$ ETS processing signal. Preincubation with the X293 RNA inhibits complex formation on the radiolabeled rRNA added subsequently (Fig. 2B, lane 5), whereas preincubation with processing-incompetent X2934l or $X 293 \Delta r$ RNA or with pUC RNA does not (lanes $4,6,7)$. Furthermore, this oocyte-formed complex comigrates with the specific complex that forms on X293 RNA in an extract of Xenopus kidney tissue culture cells (Fig. 2B, lane 1; Mougey and Sollner-Webb, 1993|. This indicates that Xenopus oocyte nuclear factors assemble a specific complex on exogenously added copies of the 5' ETS processing signal.

From the amount of $5^{\prime}$ ETS complex formed by the oocyte nuclear components (Fig. 2B, data not shown) and the number of pre-rRNA molecules per oocyte (SollnerWebb and McKnight 1982), we calculate that the oocyte has a capacity for complex formation that is $\sim 10 \%$ in excess over its endogenous content of pre-rRNA molecules. This is approximately the same as the capacity for complex formation by the tissue culture cell extract, calculated relative to that cell's pre-rRNA content /data not shown). Thus, although oocytes exhibit only a limited extent of 5' ETS processing (Fig. 2A), they appear to have an excess of the components needed to form the specific 5' ETS complex.

The size of the 5' ETS complex formed by the Xenopus oocyte factors was assessed using velocity centrifugation. The complex on X293 RNA has a sedimentation coefficient of $\sim 20 \mathrm{~S}$ (Fig. $2 \mathrm{C}$ ). This is the same $S$ value as for the $5^{\prime}$ ETS processing complexes formed on mouse pre-rRNA in the mouse cell extract (Kass and SollnerWebb 1990) and that formed on Xenopus pre-RNA in the kidney cell extract (Mougey and Sollner-Webb, 1993). It is also approximately the sedimentation coefficient of four nucleosomes. The $5^{\prime}$ ETS processing complex, therefore, must be a sizable structure, presumably $>100 \AA$ in diameter, that should be visible in electron microscopic spreads.

Although the biochemical analysis shows that Xenopus oocytes have sufficient capacity for the formation of a processing-related complex of the appropriate size to be a terminal ball structure, there are statements in the literature indicating that terminal balls only form on pre-rRNA molecules that are several kilobases in length (e.g., Puvion-Dutilleul et al. 1977b; Franke et al. 1979; based on observations in Triturus and rat), posing a potential counterargument to this hypothesis. These observations were interpreted to indicate that terminal ball formation involves rRNA sequences located kilobases beyond the 5' ETS processing segment, but alternatively they could reflect the kinetics of terminal ball formation in these organisms. In fact, re-examination of electron microscopic spreads from Xenopus oocytes showing nascent transcripts of cellular rRNA genes (Miller and Beatty $1969 a_{i}$ Fig. 3A) and showing transcripts on microinjected full-length rRNA genes (Trendelenburg and Gurdon 1978; Bakken et al. 1982; Fig. 3B) demonstrates terminal balls already on short RNAs near the $5^{\prime}$ end of the transcription unit (Fig. 3A,B). They can be seen on the transcripts by the third or fourth polymerase, which is the electron-dense bead at the base of each transcript, located every $80-100$ nucleotides along the gene. Therefore, terminal balls can form on Xenopus pre-rRNAs that are $\sim 300-400$ nucleotides in length. This coincides well with the region shown above for direct formation of the processing complex.

To investigate the correlation of terminal balls with the 5' ETS processing complex, we first prepared a derivative of a full-length rRNA gene from which was deleted a 2-kb segment including the $5^{\prime}$ ETS-processing signal /the segment beginning at residue +13 and encompassing the rest of the ETS and most of the $18 \mathrm{~S}$ region; diagramed at the bottom of Fig. 4). Upon microinjection into Xenopus oocyte nuclei, this $E A \cdot 3^{\prime}$ gene is actively transcribed; Figure 4 is a montage of resultant micrographs and their tracings. Rather than forming Christmas trees, however, the $E A \cdot 3^{\prime}$ construct forms pine trees, with nascent transcripts lacking the usual terminal decorations. Terminal balls can be assessed easily by comparing the ends of the transcripts with the granules representing the RNA polymerase molecules along the DNA axis (Fig. 3 and 4). The endogenous cellular rRNA genes present in these same spreads displayed the usual terminal ball structures/data not shown). Thus, terminal ball formation requires rRNA sequences within the 2-kb segment downstream from residue +13 , including the $5^{\prime}$ ETS processing site. This result also indicates that terminal ball formation is not inherent in the RNA polymerase I transcriptional process per se or in the $5^{\prime}$ polyphosphate terminus of the resultant transcripts.

To determine whether the rRNA sequences of the $X 293$ construct that direct formation of the processing complex (Fig. 2B; Mougey and Sollner-Webb, 1993) also support terminal ball formation, the 266-bp rDNA segment from the X293 gene was inserted into the $5^{\prime}$ portion of the transcribed region of the $E A \cdot 3^{\prime}$ gene, yielding EA293.3' (rRNA residues 28-293; see Materials and methods). The processing-competent $X 293$ segment is now present at the $5^{\prime}$ end of each transcript. After microinjection into Xenopus oocytes and electron microscopic visualization, EA293.3' is seen to form transcription complexes of the Christmas tree variety, with transcripts bearing terminal balls. Representative resultant micrographs are shown in Figure 5. Thus, the same small rRNA segment that directs assembly of the biochemically detected processing complex also directs terminal ball formation.

The data in Figure 6 demonstrate that the same 11nucleotide conserved region is critical for terminal ball 


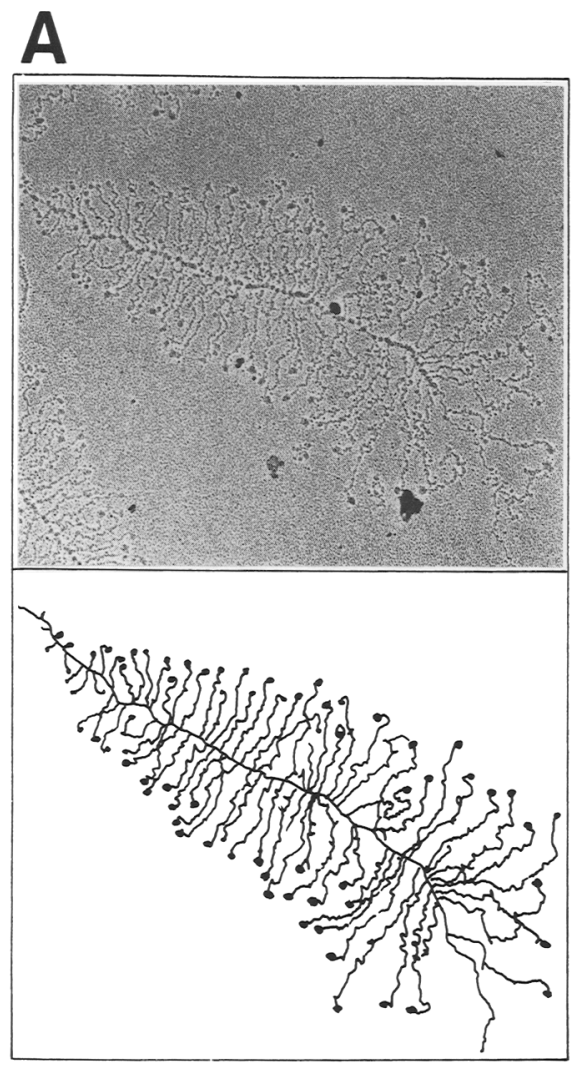

B
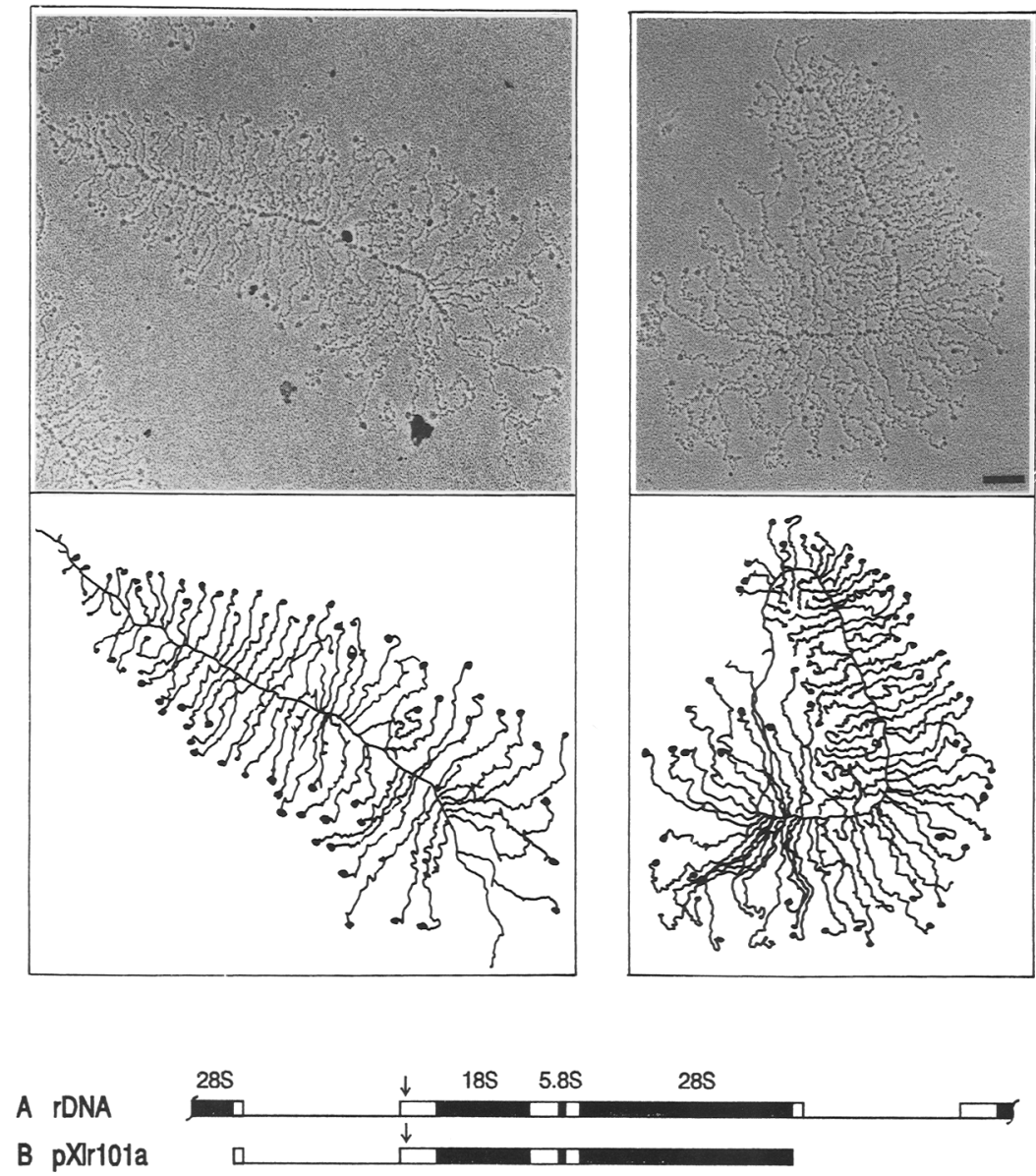

Figure 3. Electron microscopic visualizations of transcription units on intact rRNA genes. $(A) X$. laevis oocyte nuclei were isolated, and their contents dispersed and deposited on grids by the chromatin spreading and electron microscopic visualization technique of Miller and Beatty (1969a; Miller and Bakken 1972). A transcription unit from an amplified genomic rRNA gene array is shown, as well as a tracing of the micrograph. The beads representing the polymerase at the base of each transcript are not shown in the tracings. $(B)$ pXlr101a, a complete repeating unit of $X$. laevis rDNA cloned into pBR322, was microinjected into the nuclei of $X$. laevis oocytes, which were subsequently spread and visualized as in $A$. Bar, $0.2 \mu \mathrm{m}$. Below is a diagram of a segment of the genomic rDNA repeat and the cloned rDNA repeating unit present in pXlr101a. Arrows indicate the $5^{\prime}$ ETS processing site. formation and for rRNA processing complex formation. To this end, we prepared a construct identical to EA293.3', except that the 11-nucleotide critical segment of the processing signal was inactivated by the $\Delta \mathrm{l}$ mutation. This mutation makes the RNA incompetent for processing complex formation (see Fig. 2B). Transcription complexes visualized from this EA293Al.3' construct, after its microinjection into Xenopus oocytes, are again of the pine tree variety-densely packed transcript branches lacking terminal ball structures (Fig. 6). Because the processing complex assayed biochemically by gel retardation, velocity centrifugation, and competition ability is a large structure that forms on the same small rRNA region and requires the same critical residues as the terminal ball structures detected by electron microscopy, we conclude that the latter structure is the ultrastructural visualization of the former.

\section{Discussion}

When visualized by electron microscopy in spread chromatin preparations, transcribing rRNA genes are known to form Christmas tree-like structures with terminal balls characteristically decorating the $5^{\prime}$ ends of the na- scent rRNA branches (Miller and Beatty 1969a). The identity and role of these terminal balls has remained unknown, despite their observation in scores of species, reported in well over a hundred publications (representative references are listed in the introductory section). In a separate study, a site of processing complex formation has been identified in the $X$. laevis precursor rRNA at residue +105 of the $5^{\prime}$ ETS, 600 nucleotides upstream of the 18S region (Fig. 2; Mougey and Sollner-Webb, 1993; Fig. 1). This processing in the frog is the analog of $5^{\prime}$ ETS processing in the mouse (Miller and Sollner-Webb 1981), and it directs formation of a specific complex in Xenopus oocytes as well as in Xenopus tissue culture cells. The large structures that the processing region of both frog and mouse assemble with factors of the cell extract sediment at $\sim 20 \mathrm{~S}$ (Fig. 2B,C; Kass and SollnerWebb 1990). The Xenopus and mouse 5' ETS processing signals also share a common 11-nucleotide sequence just beyond the processing site that is required both for the processing and for specific complex assembly, in both the frog and mouse systems (Fig. 1 and 2B; Mougey and Sollner-Webb, 1993). We will now summarize the considerable evidence that this $5^{\prime}$ ETS processing complex is the ultrastuctural basis for the terminal balls. 
Figure 4. Electron microscopic visualization of active $E A \cdot 3^{\prime}$ genes. The plasmid $E A \cdot 3^{\prime}$ was microinjected, spread, and visualized as in Fig. 3B. Three examples with tracings are shown. Note that terminal balls, which in Fig. 3 were larger than the polymerases, are not observed on the $E A \cdot 3^{\prime}$ plasmid transcripts. In these same spreads, the chromatin of the endogenous cellular rRNA genes showed terminal balls, as in Fig. 3A. For all plasmids studied, at least 15 well-spread molecules were examined, and all showed patterns typified by the presented micrographs. Bar, $0.2 \mu \mathrm{m}$. In the diagram aligned below the rDNA repeat are shown those rDNA segments plus the marker segment (the small box below the line) that are cloned to form $E A \cdot 3^{\prime}$. The $E A \cdot 3^{\prime}$ transcript lacks a 2 -kb segment present in the genomic rRNA transcript, starting at residue +28 .
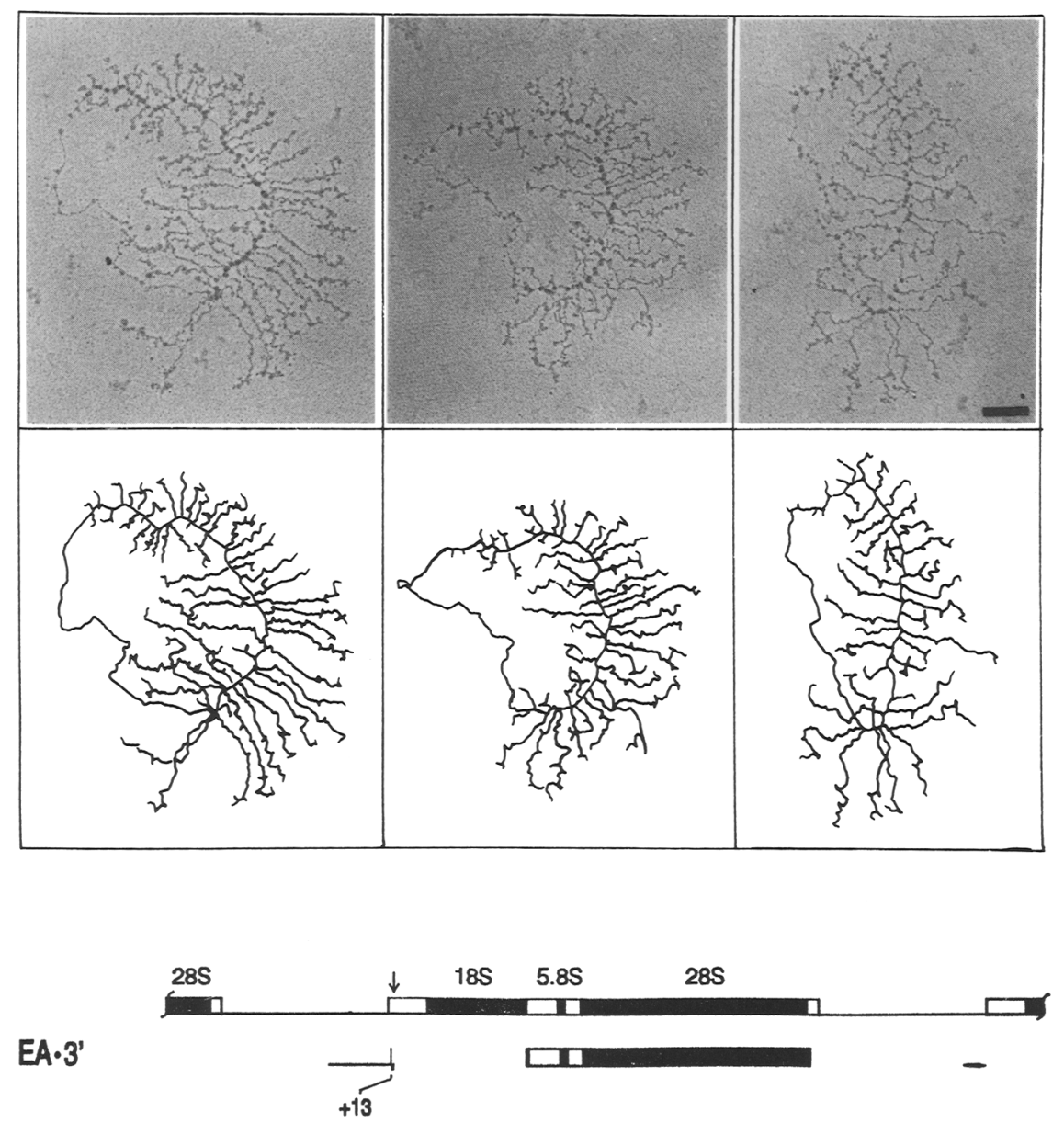

Terminal balls cannot be the result of condensation of several kilobases of the primary ribosomal transcript, as had been proposed (Puvion-Dutilleul et al. 1977b; Franke et al. 1979), as they are already present on Xenopus prerRNA transcripts of $\sim 300$-nucleotide length (Fig. 3). This can also be concluded from re-examining published micrographs of X. laevis spreads (e.g., McKnight and Miller 1976; Trendelenburg 1981) and from transcript mapping (Osheim and Beyer 1985; see also Discussion in Miller and Bakken 1972). The terminal balls also cannot be inherent to RNA polymerase I-catalyzed transcription units, as they are not observed on spreads of transcribing plasmid $E A \cdot 3^{\prime}$, which uses the rDNA promoter (Fig. 4). Re-examination of published micrographs shows that terminal balls were also absent from the RNA polymerase I-catalyzed transcription units that are occasionally observed in ribosomal "nontranscribed spacer" regions (Franke et al. 1979; Trendelenburg 1981, 1982).

When rRNA residues through +293 are included on an RNA polymerase I-catalyzed transcription unit, terminal balls are observed (Fig. 5). Because this region is substantially upstream of the $18 \mathrm{~S} / 5.8 \mathrm{~S} / 28 \mathrm{~S}$ coding regions, terminal balls cannot involve rRNA sequences that will end up in the mature ribosome, as had been inherent in various suggested models for the nature of the terminal balls (Puvion-Dutilleul et al. 1977b; Franke et al. 1979; Puvion-Dutilleul 1983; Osheim and Beyer 1985).

Although terminal ball formation requires only rRNA sequences in the $5^{\prime}$ portion of the $5^{\prime}$ ETS, these structures do not form on the transcripts of a plasmid containing the subcloned rDNA promoter/initiation region extending through RNA residue +113 , as revealed by re-examination of published micrographs (pX1r14D; Bakken et al. 1982). These data point to the importance of the frog sequence between residue +113 and +293 in terminal ball formation. This region corresponds closely with the frog-conserved 5 ' ETS processing sequence, residues +112 through $\sim+233$ (Mougey and Sollner-Webb, 1993).

When the 11-nucleotide conserved element in the $5^{\prime}$ ETS processing signal is inactivated with the $\Delta 1$ deletion, neither terminal ball formation nor the biochemically detected complex formation is observed (Fig. 2B and 6). This demonstrates that the evolutionarily conserved sequence element that is necessary for $5^{\prime}$ ETS processing and complex formation is also essential for terminal ball formation.

Our conclusion that the terminal ball is the $5^{\prime}$ ETS processing complex is also supported by high-resolution 

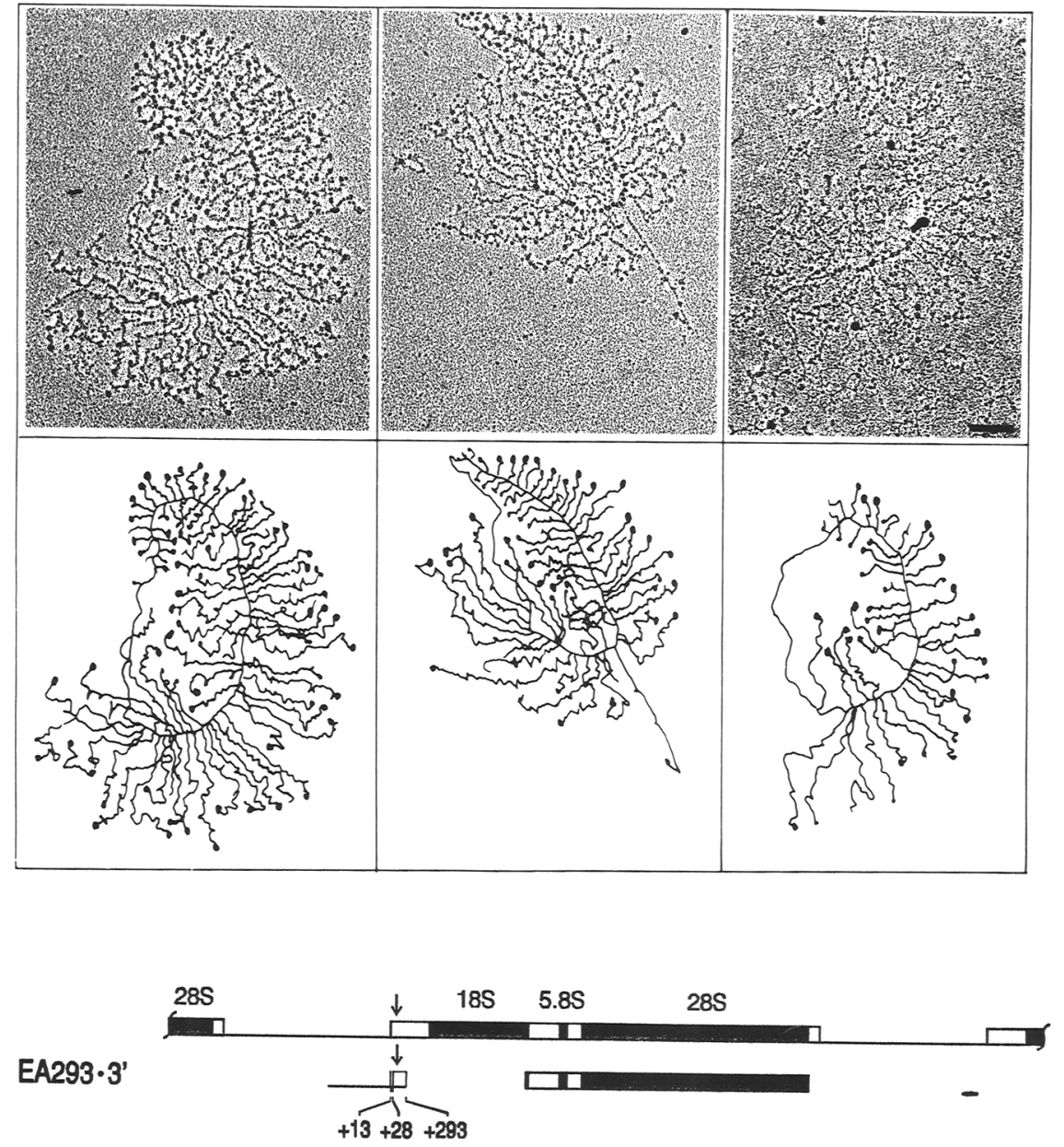

Figure 5. Electron microscopic visualization of active $E A 293 \cdot 3^{\prime}$ genes. The plasmid EA293.3' was microinjected, spread, and visualized as in Fig. 3B. Three examples with tracings are shown. Terminal balls are observed. Bar, $0.2 \mu \mathrm{m}$. In the diagram, the segments cloned to form EA293.3' are shown below the rDNA repeat. EA293.3' is like $E A \cdot 3^{\prime}$ but with the $28-293$ rDNA segment inserted near the $5^{\prime}$ end of the transcribed region. micrographs of $\mathrm{CHO}$ ribosomal transcription units (Puvion-Dutilleul et al. 1977a). These micrographs show that the "terminal" balls in this species are not truly terminal but frequently have a short RNA whisker protruding $5^{\prime}$ from the ball. Such $5^{\prime}$ terminal whiskers might be expected from the $\sim 650$ nucleotides of rRNA upstream of the CHO 5' ETS processing complex. We predict that high resolution spreads of other rodent rRNA transcripts would show similar terminal whiskers, corresponding to the $\sim 650$ - to 800 -nucleotide segments upstream of their $5^{\prime}$ ETS-processing signal. Indeed, re-examination of a published micrograph of a mouse ribosomal transcription unit (Scheer and Benavente 1990) also appears to show such whiskers $5^{\prime}$ of the terminal balls. In contrast, any potential $5^{\prime}$ whisker in spreads from frog would be only $\leqslant 100$ nucleotides in length and therefore would not be expected to be obvious in chromatin spreads.

Fibrillarin is a polypeptide that can be found associated with numerous nucleolar snRNAs [U3, U8, U13, U14, X, and Y (for review, see Fournier and Maxwell 1993; Sollner-Webb et al. 1993)]. In situ localization using an anti-fibrillarin antibody has demonstrated the presence of this antigen in the terminal balls of ribosomal transcription units (Scheer and Benavente 1990).
This result also supports our concept of the terminal balls, because the U3 snRNP (which contains fibrillarin) has been shown to bind to this $5^{\prime}$ ETS processing complex in vitro (Kass et al. 1990) and to be present on the $5^{\prime}$ ETS in the vicinity of this processing site in vivo (Maser and Calvet 1989; Stroke and Weiner 1989).

Transcription units visualized on genes transcribed by RNA polymerase II do not typically show terminal balls (e.g., Miller and Bakken 1972; McKnight and Miller 1976; Puvion-Dutilleul et al. 1977b), as noted above. However, balls (or "granules") that are generally internal (but occasionally near the $5^{\prime}$ end of the RNA) have been observed, and these are concluded to be the spliceosome complexes involved in pre-mRNA processing (Osheim et al. 1985; Beyer and Osheim 1988). These pre-mRNA internal balls frequently first arise as pairs of smaller balls, arguably the $5^{\prime}$ and the $3^{\prime}$ splice site complexes, which later (further down the transcription unit) appear to aggregate and can reveal a looped-out intron. Still later, this intron loop may no longer be visualized, indicating that the complete splicing reaction has taken place. Thus, there is precedent for granules seen on nascent RNA in electron microscopic chromatin spreads to be processing complexes.

The rRNA terminal balls are $\sim 250 \AA$ in diameter 
Figure 6. Electron microscopic visualization of active $E A 293 \Delta 1 \cdot 3^{\prime}$ genes. The plasmid EA293Al.3' was microinjected, spread, and visualized as in Fig. 3B. Three examples with tracings are shown. Terminal balls are not observed on EA2934l.3' plasmids, but they were present on the chromatin of the endogenous cellular rRNA genes. Bar, $0.2 \mu \mathrm{m}$. The diagram shows the segments cloned to form $E A 293 \Delta 1 \cdot 3^{\prime}$, which is the same as EA293.3' except for bearing the $\Delta \mathrm{l}$ deletion of the critical 11-nucleotide segment just beyond the $5^{\prime}$ ETS processing site at +105 .
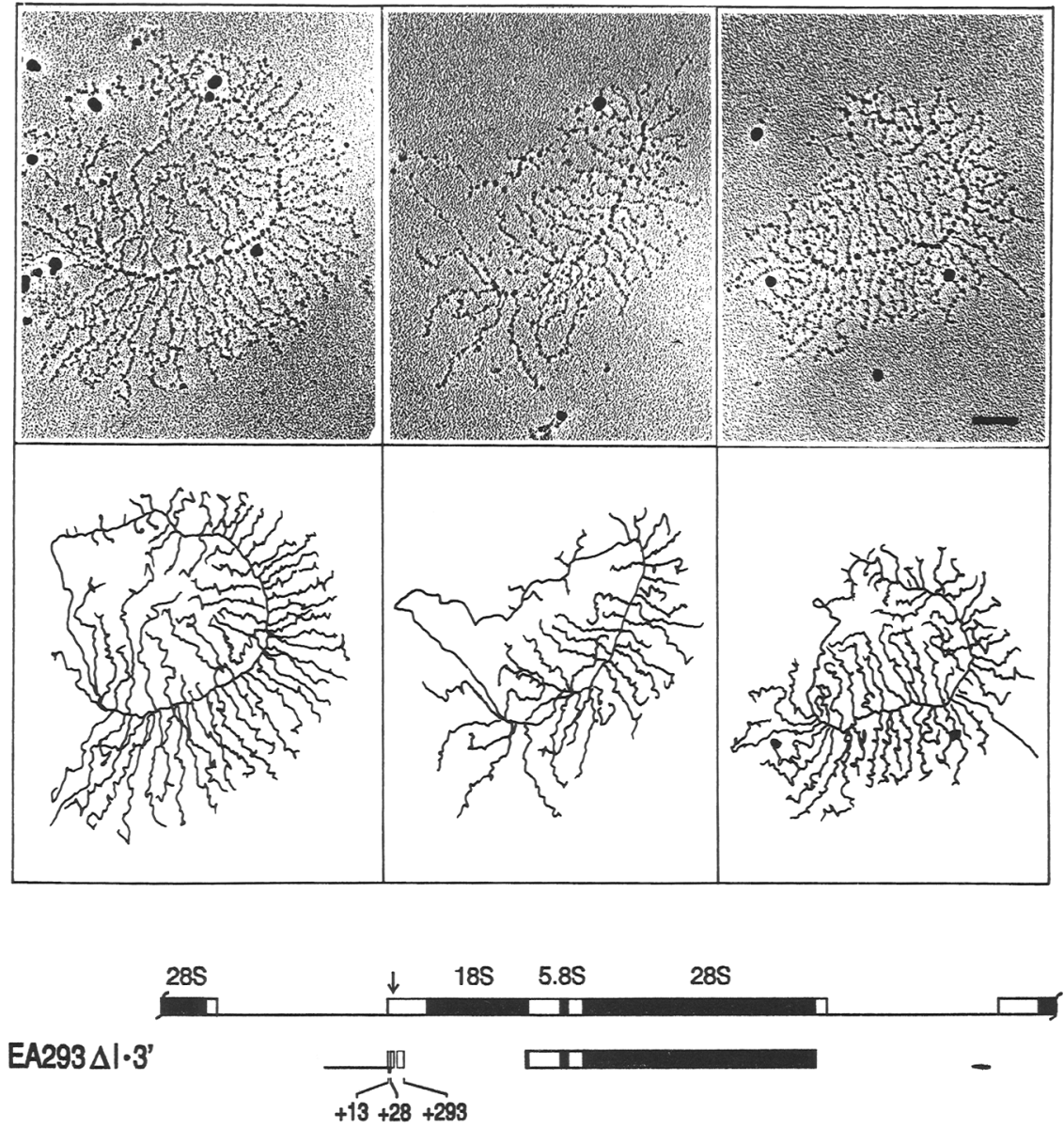

(Miller and Bakken 1972; Puvion-Dutilleul et al. 1977b), approximately the size of the complexes on the $5^{\prime}$ and the 3' splice sites of the pre-mRNAs (Osheim et al. 1985; Beyer and Osheim 1988/. This suggests that the ETS complex on the intact rRNA gene is a sizable entity, most likely containing components in addition to the four polypeptides identified as binding to this region by UV cross-linking (Mougey and Sollner-Webb, 1993) plus the U3 snRNP. Nonetheless, the ETS processing complex is considerably smaller than the complete spliceosome complex $(\sim 400 \AA$ in diam.; Osheim et al. 1985; Beyer and Osheim 1988), indicating that it consists of considerably fewer species than the $\sim 100$ polypeptides plus $\sim 5$ snRNAs of the complete spliceosome.

Because the terminal balls seen in ribosomal spreads from amphibians and mammals are concluded to be the ETS processing complex, we argue that this is also the case in the vast number of other eukaryotes whose rRNA gene transcripts all showed terminal balls when examined by electron microscopy (representative references in the introductory section; Franke et al. 1979). Consistent with this hypothesis that all eukaryotes form a $5^{\prime}$ ETS processing complex on their nascent rRNA, molecular analysis of the pre-rRNA of numerous species has revealed more than one $5^{\prime}$ end location, with the downstream end shown to result from rRNA processing $[\mathrm{Neu}$ - rospora (Tyler and Giles 1985); yeast (Hughes and Ares 1991/] or inferred to derive in this manner [Physarum (Blum et al. 1986); Tetrahymena (Sutiphong et al. 1984); Bombyx (Fujiwara and Ishikawa 1987); maize (McMullen et al. 1986); wheat (Barker et al. 1988); pea (Piller et al. 1990)]. The $5^{\prime}$ processing in yeast is also known to require the U3 snRNP (Hughes and Ares 1991). It now seems likely that all of these species will have a $5^{\prime}$ ETS processing that involves formation of a large terminal ball complex and will be U3-requiring and otherwise analogous to the processing events of mouse and frog. Other cell types might show little or no actual 5' ETS processing, yet will assemble a terminal ball complex, akin to the situation in Xenopus oocytes.

It is notable that the efficiency of ETS processing varies widely. The processed species comprises $\sim 90 \%$ of precursor rRNA in mouse cells (Miller and Sollner-Webb 1981 ), $\sim 50 \%$ in human cells (Kass et al. 1987), $\sim 30 \%$ in Xenopus kidney cells (Mougey and Sollner-Webb, 1993) and in Xenopus follicle cells (data not shown), and $\sim 1 \%$ in Xenopus oocytes (Fig. 2A). Nonetheless, processing complex formation evidently occurs efficiently on the nascent ribosomal transcripts in all eukaryotic cell types, as shown by electron microscopic visualization of rRNA terminal balls (references above). This suggests that what has been conserved in evolution may not be 
the act of $5^{\prime}$ ETS processing per se, but rather the ability to form a processing complex in the $5^{\prime}$ ETS and its assembly relatively early during the transcription process.

The ubiquitious presence of 5 ' ETS processing complex formation across eukaryotes (unicellular and multicellular, plants and animals) indicates that it offers an evolutionarily advantageous function. Because this processing complex forms in the $5^{\prime}$ ETS region of the prerRNA, which ultimately will be destroyed and not become part of the ribosome, it is tempting to hypothesize that it functions to aid in later processing steps of the pre-rRNA. During pre-rRNA transcription and its concurrent assembly into RNP (Chooi and Leiby 1981), the large nascent transcripts are packed very densely, and this mass could shield later processing sites from rapid processing complex formation. Processing factors present in cis on the rRNA, assembled when the nascent transcript was short and a binding site was more available, could serve to facilitate downstream cleavages. Consistent with this proposal, a site needed for U3 binding (and presumably for a complex formation) in the $5^{\prime}$ ETS of yeast is required for the subsequent processing of the 18S segment in vivo (Beltrame and Tollervey 1992).

\section{Materials and methods}

\section{Plasmid constructs}

$X 293$ was generated by inserting $X$. laevis rDNA residues +28 to +293 [a NarI fragment from rDNA clone $p X 1 r 14 a$ (SollnerWebb and Reeder 1979/] into the AccI site of pGEM3, downstream from the $\mathrm{T} 7$ promoter. The 11-nucleotide block, conserved between frog and mammals (Fig. 2A), extends from residue +112 to +122 . X2934l is a derivative of X293 in which rDNA residues +105 to +119 were deleted by Bal 31/S1 digestion, starting from the $P v u I$ site at residue +113 (partial digest), followed by recircularization of the plasmid. $X 293 \Delta r$ is a derivative of $X 293$ in which residues +113 to +134 were deleted by inserting a SmaI-NotI fragment (residues +135 to +177 ) in place of a PvuI (blunted)-NotI fragment (residues +113 to +177 ). All deletion end points were determined by sequence analysis (Maxam and Gilbert 1977). pXlr101a contains the entire X. laevis rDNA repeating unit (Bakken et al. 1982) inserted into pBR322 by HindIII cleavage and ligation. $E A \cdot 3^{\prime}$ contains the $X$. laevis rDNA enhancer/promoter/marker region from plasmid EA (Pape et al. 1989; rDNA residues -1147 to +13 ) joined upstream of the last two-thirds of the rDNA-coding region (the 5.15-kb XbaI-HindIII fragment from $p X l r 101 a$ that starts 60 nucleotides before the end of the $18 \mathrm{~S}$ region) and then the T3 fail-safe termination region (the HaeIII fragment from residue -243 to -188 upstream of the promoter|, cloned in SalI-EcoRI-cut pBR322. EA293 ' $3^{\prime}$ is like EA $\cdot 3^{\prime}$ except that the +28 to +293 region of $X 293$ has been added between the EA region and the $3^{\prime}$ rRNA region. $E A 293 \Delta l \cdot 3^{\prime}$ is the same as $E A 293 \cdot 3^{\prime}$ except that the +28 to +293 region bears the +105 to +119 deletion from $X 293 \Delta$ l.

\section{S1 nuclease analysis}

RNA, prepared from logarithmically growing cultures of $X$. laevis kidney cells $(\sim 12 \mu \mathrm{g})$, from manually isolated $X$. laevis oocyte nuclei (two germinal vesicles, GVs), and from follicle cells (Henderson and Sollner-Webb 1986; Windle and SollnerWebb 1986) was hybridized to 40 fmoles of strand-separated probe and digested with S1 nuclease (Sollner-Webb and McKnight 1982). The $X$. laevis ETS probe corresponds to the $5^{\prime}$ portion of the $X 293$ transcript, an EcoRI-NotI fragment, 5' labeled at the NotI site at +179 . The products were analyzed on a $9 \mathrm{M}$ urea/8\% polyacrylamide gel. The marker (Maxam and Gilbert 1977) sequencing track of the probe DNA migrates $1 \frac{1 / 2}{2}$ nucleotides faster than the corresponding fragment generated by S1 nuclease (Sollner-Webb and Reeder 1979).

\section{In vitro reaction and complex formation}

$X$. laevis oocyte nuclei were isolated manually (Wilkinson and Sollner-Webb 1982), homogenized by pipetting, and clarified by centrifugation at $12,000 \mathrm{~g}$ for $30 \mathrm{sec}$ at $4^{\circ} \mathrm{C}$. Where indicated, S-100 extract of log phase $X$. laevis kidney cells (line Xl-K2) propagated in tissue culture was used (McStay and Reeder 1990). The substrate and competitor RNAs were transcribed from the T7 promoter of the appropriate plasmid, linearized at the HindIII site in the polylinker downstream of the rDNA region, and gel isolated as described (Kass and Sollner-Webb 1990). The substrate RNAs were labeled with ${ }^{32} \mathrm{P}$ and the competitor RNAs with ${ }^{3} \mathrm{H}$, the latter for quantitation.

The $25-\mu 1$ in vitro reactions were at a final concentration of 20 mM HEPES (pH 7.9), $120 \mathrm{~mm} \mathrm{KCl,} 2 \mathrm{mM} \mathrm{MgCl}, 9 \%$ glycerol, 2 mM DTT, $0.14 \mathrm{mM}$ EDTA, and $1.5 \mathrm{~mm}$ ATP and contained 40 units of RNAsin (Promega). They also contained four GVs worth of oocyte nuclear homogenate and 8.0 fmoles of labeled RNA substrate. The extract was preincubated for $60 \mathrm{~min}$ with a 40-fold molar excess of the indicated competitor RNA, and the substrate RNA was then added and incubation continued for an additional $90 \mathrm{~min}$. The reactions were then brought to $260 \mu \mathrm{g} /$ $\mathrm{ml}$ of heparin and incubated for an additional $10 \mathrm{~min}$ at $20^{\circ} \mathrm{C}$. A $10-\mu l$ aliquot was directly analyzed on a native $4 \%$ polyacrylamide gel (65:1 acrylamide/bis), as described (Kass and Sollner-Webb 1990). Sucrose gradient analysis of the assembled nucleoprotein uses a scaled-up processing reaction of $75 \mu \mathrm{l}$ containing $36 \mathrm{GVs}$ and 72 fmoles of X293 RNA. The reaction was treated as for mobility shift, except that the heparin was brought to $400 \mu \mathrm{g} / \mathrm{ml}$ and the reaction was then brought to 100 $\mu l$ by addition of gradient buffer (reaction buffer lacking glycerol and ATP but containing $0.5 \mathrm{mM} \mathrm{MgCl}{ }_{2}$ ). It was layered onto a $5-\mathrm{ml} 5-20 \%$ sucrose gradient in gradient buffer and sedimented at $50,000 \mathrm{rpm}, 20^{\circ} \mathrm{C}$ in the SW55 rotor for $\sim 2.5 \mathrm{hr}$. Twenty-three fractions of $225 \mu \mathrm{l}$ were collected from the top, and $100 \mu \mathrm{l}$ of each was analyzed by mobility shift.

\section{Microinjection and spreading of oocyte nuclei and electron microscopic visualization of the ribosomal chromatin}

Clumps of excised $X$. laevis ovary were defolliculated in cold $0.2 \%$ collagenase (Type II, Sigma) in $\mathrm{Ca}^{2+}$-free modified Barth's solution (MBS) (Gurdon 1976) with shaking for $3 \mathrm{hr}$, washed extensively in cold complete MBS, and incubated in MBS overnight at $18^{\circ} \mathrm{C}$ (Coleman 1984). For injections, oocytes were placed on a 1-mm Nitex mesh screen covered with $5 \%$ Ficoll (Sigma) in MBS. Approximately a $40 \mathrm{nl}$ volume was injected into each germinal vesicle. The plasmid DNA for injection was at $0.5 \mathrm{mg} / \mathrm{ml}$ and was dissolved in $10 \mathrm{mM}$ Tris- $\mathrm{HCl}(\mathrm{pH} 7.6), 0.1$ $\mathrm{mM}$ EDTA, and $200 \mu \mathrm{g} / \mathrm{ml}$ of $\alpha$-amanitin. After injection, oocytes were allowed to recover in $5 \%$ Ficoll in MBS for 1-2 hr, rinsed extensively with MBS, and incubated in MBS for 4-24 hr at $18^{\circ} \mathrm{C}$. Chromatin dispersal and electron microscopic visualizations were as described previously (Miller and Bakken 1972). More than 15 examples of each transcribing plasmid were examined, and in each case, all showed the same patterns as the 
examples in the figures shown for each plasmid. The ribosomal transcription units of the plasmids are readily distinguished from those on the endogenous rRNA genes by their presence on a small circular molecule of the appropriate size, rather than in long tandem arrays.

\section{Acknowledgments}

We are indebted to Drs. Brian McStay and Ron Reeder for Xenopus cell S-100 extract and to Dr. Don Brown and Ms. Eddie Jordan for Xenopus cell cultures. We also thank Drs. Joan Steitz, Mike Wormington, Louise Pape, Nessly Craig, and Cathy Enright and other members of the Sollner-Webb laboratory for helpful discussions and Drs. Don Cleveland, Ken Piller, and Nick Theodorakis for helpful reading of the manuscript. We also acknowledge Ms. Mary Bonkowski for help in preparation of the manuscript. This work was supported by grants GM21020, GM27720, ACSNP731, and NSFDCB9004860 to B.S.-W., O.L.M., Jr., and A.B., respectively.

The publication costs of this article were defrayed in part by payment of page charges. This article must therefore be hereby marked "advertisement" in accordance with 18 USC section 1734 solely to indicate this fact.

\section{References}

Bakken, A., G. Morgan, B. Sollner-Webb, J. Roan, S. Busby, and R. Reeder. 1982. Mapping the transcription initiation and termination signal on Xenopus laevis ribosomal DNA. Proc. Natl. Acad. Sci. 79: 56-60.

Barker, R.F., N.P. Harberd, M.G. Jarvis, and R.B. Flavell. 1988 Structure and evolution of the intergenic region in a ribosomal DNA repeat unit of wheat. J. Mol. Biol. 210: 1-17.

Beltrame, M. and D. Tollervey. 1992 Identification and functional analysis of two U3 binding sites on yeast pre-ribosomal RNA. EMBO $/$. 11: 1531-1542.

Beyer, A.L. and Y.N. Osheim. 1988. Splice site selection, rate of splicing, and alternative splicing on nascent transcripts. Genes \& Dev. 2: 745-765.

Blum, B., G. Pierron, T. Seebeck, and R. Braun. 1986. Processing in the external transcribed spacer of ribosomal RNA from Physarum polycephalum. Nucleic Acids Res. 14:31533166.

Bourbon, H., B. Michot, N. Hassouna, and J.P. Bachellerie. 1988. Sequence and secondary structure of the $5^{\prime}$ external transcribed spacer of mouse pre-rRNA. DNA 7: 181-191.

Chooi, W.Y. and K.R. Leiby. 1981. An electron microscopic method for localization of ribosomal proteins during transcription of ribosomal DNA: A method for studying protein assembly. Proc. Natl. Acad. Sci. 78: 4823-4827.

Coleman, A. 1984. Expression of exogenous DNA in Xenopus oocytes. In Transcription and translation: A practical approach (ed. B.D. Hames and S.J. Higgins) pp. 49-68 and 271300. IRL Press, Washington, D.C.

Craig, N., S. Kass, and B. Sollner-Webb. 1987. Nucleotide sequence determining the first cleavage site in the processing of mouse precursor ribosomal RNA. Proc. Natl. Acad. Sci. 84: 629-633.

- 1991. Sequence organization and RNA structural motifs directing the mouse primary rRNA processing event. Mol. Cell. Biol. 11: 458-467.

Foe, V.E. 1978. Modulation of ribosomal RNA synthesis in Oncopeltus fasciatus: An electron microscopic study of the relationship between changes in chromatin structure and transcription activity. Cold Spring Harbor Symp. Quant. Biol.
42: 723-740.

Fournier, M.J. and E.S. Maxwell. 1993. The nucleolar snRNAs: Catching up with the spliceosomal snRNAs. Trends Biochem. Sci. 18: 131-135.

Franke, W.W., U. Scheer, H. Spring, MF. Trendelenburg, and H. Zentgraf. 1979. Organization of nucleolar chromatin. In The cell nucleus, vol. 7, pp. 49-95. Academic Press, New York.

Fujiwara, H. and H. Ishikawa. 1987. Structure of the Bombyx mori rDNA: Initiation site for its transcription. Nucleic Acids Res. 15: 1245-1258.

Furlong, J.C., J. Forbes, M. Robertson, and B.E.H. Madden. 1983. The external transcribed spacer and preceding region of Xenopus borealis rDNA: Comparison with the corresponding region of Xenopus laevis rDNA. Nucleic Acids Res. 11: 8183-8196.

Grainger, R.M. and R.C. Ogle. 1978. Chromatin structure of the ribosomal RNA genes in Physarum polycephalum. Chromosoma 65: 115-126.

Greimer, R. and R. Deltour. 1984. Visualization of transcribing nucleolar genes in a higher plant. Biol. Cell. 50: 237-246.

Gurdon, J.B. 1976. Injected nuclei in frog oocytes: Fate, enlargement and chromatin dispersal. J. Embryol. Exp. Morphol. 36: $523-540$

Gurney, T. 1985. Characterization of mouse 45S ribosomal RNA subspecies suggests that the first processing cleavage occurs $600 \pm 100$ nucleotides from the $5^{\prime}$ end and the second $500 \pm 100$ nucleotides from the $3^{\prime}$ end of a $13.9 \mathrm{~kb}$ precursor. Nucleic Acids Res. 13: 4905-4919.

Hamkalo, B.A., O.L. Miller, Jr., and A.H. Bakken. 1973. Ultrastructure of active eukaryotic genomes. Cold Spring Harbor Symp. Quant. Biol. 38: 915-919.

Henderson, S. and B. Sollner-Webb. 1986. A transcriptional terminator is a novel element of the promoter of the mouse ribosomal RNA gene. Cell 47: 891-900.

Hughes, J.M.X. and M. Ares, Jr. 1991. Depletion of U3 small nucleolar RNA inhibits cleavage in the $5^{\prime}$ external transcribed spacer of yeast pre-ribosomal RNA and impairs formation of 18S ribosomal RNA. EMBO /. 10: 4231-4239.

Jamrich, M., E. Clark, and O.L. Miller, Jr. 1979. Absence of nucleosomes in the actively transcribed rDNA of Calliphora erythrocephala larval tissue and of quail myoblasts. ICNUCLA Symp. Mol. Cell. Biol.: Eukaryotic gene regulation 14: $573-580$.

Kass, S. and B. Sollner-Webb. 1990. The first pre-rRNA processing event occurs in a large complex: Analysis by gel retardation, sedimentation, and UV crosslinking. Mol. Cell. Biol. 10: $4920-4931$.

Kass, S., N. Craig, and B. Sollner-Webb. 1987. The primary processing of mammalian rRNA involves two adjacent cleavages and is not species specific. Mol. Cell. Biol. 7: 28912898.

Kass, S., K. Tyc, J. Steitz, and B. Sollner-Webb. 1990. The U3 small nucleolar ribonucleoprotein functions in the first step of pre-ribosomal RNA processing. Cell 60: 897-908.

Maser, R.L. and J.P. Calvet. 1989. U3 small nuclear RNA can be psoralen cross-linked in vivo to the $5^{\prime}$ external transcribed spacer of pre-ribosomal RNA. Proc. Natl. Acad. Sci. 86: 6523-6527.

Maxam, A. and W. Gilbert. 1977. A new method for sequencing DNA. Proc. Natl. Acad. Sci. 74: 560-564.

McKnight, S.L. and O.L. Miller, Jr. 1976. Ultrastructural patterns of RNA synthesis during early embryogenesis of Drosophila melanogaster. Cell 8: 305-319.

McKnight, S.L., N.L. Sullivan, and O.L. Miller, Jr. 1976. Visualization of the silk fibroin transcription unit and nascent silk fibroin molecules on polyribosomes of Bombyx mori. 
Prog. Nucleic Acid Res. Mol. Biol. 19: 313-318.

McMullen, M.D., B. Hunter, R.L. Phillips, and I. Rubenstein. 1986. The structure of the maize ribosomal DNA spacer region. Nucleic Acids Res. 14: 4953-4968.

McStay, B. and R.H. Reeder. 1990. An RNA polymerase I termination site can stimulate the adjacent ribosomal gene promoter by two distinct mechanisms in Xenopus laevis. Genes \& Dev. 4: 1240-1252.

Miller, K. and B. Sollner-Webb. 1981. Transcription of mouse rRNA genes by RNA polymerase I: In vitro and in vivo initiation and processing sites. Cell 27: 165-174.

Miller, O.L. Jr. and A.H. Bakken. 1972. Morphological studies of transcription. (Karolinska Symp. on Res. Meth. in Reprod. Endochrin.) Acta Endocrinol. (Suppl.) 168: 155-177.

Miller, O.L. Jr. and B.R. Beatty. 1969a. Visualization of nucleolar genes. Science 164: 955-957.

1969b. Extrachromosomal nucleolar genes in amphibian oocytes. Genetics (Suppl.) 61: 134-143.

Miller, O.L. Jr. and B.A. Hamkalo. 1972. Visualization of RNA synthesis on chromosomes. Int. Rev. Cytol. 33: 1-25.

Mougey, E.B. and B. Sollner-Webb. 1993. A U3 snRNP-requiring processing event in the $5^{\prime}$ external transcribed spacer of Xenopus precursor rRNA. Mol. Cell. Biol (in press).

Osheim, Y.N. and A.L. Beyer. 1985. Nascent ribonucleoprotein structure of polymerase I, II, and III gene transcripts. UCLA Symp. Mol. Cell. Biol. In Nuclear envelope structure and RNA maturation (ed. E.A. Smuckler and G.A. Clawson). pp. 277-295. Alan R. Liss, New York.

Osheim, Y.N., O.L. Miller Jr., and A.L. Beyer. 1985. RNP particles at splice junction sequences on Drosophila chorion transcripts. Cell 43: 143-151.

Pape, L., J. Windle, E. Mougey, and B. Sollner-Webb. 1989. The Xenopus rDNA $60 / 81$ bp repeats are true $5^{\prime}$ enhancers and function at the establishment of the preinitiation complex. Mol. Cell. Biol. 9: 5093-5104.

Piller, K.J., S.R. Baerson, N.O. Polans, and L.S. Kaufman. 1990. Structural analysis of the short length ribosomal DNA variant from Pisum sativum L. cv. Alaska. Nucleic Acids Res. 18: 3135-3145.

Puvion-Dutilleul, F. 1983. Morphology of transcription at cellular and molecular levels. Int. Rev. Cytol. 84: 57-101.

Puvion-Dutilleul, F., J. Bachellerie, J. Zalta, and W. Bernhard. 1977a. Morphology of ribosomal transcription units in isolated subnuclear fractions of mammalian cells. Biol. Cellulaire 30: 183-194.

Puvion-Dutilleul, F., A. Bernadac, E. Puvion, and W. Bernhard. 1977b. Visualization of two different types of nuclear transcriptional complexes in rat liver cells. J. Ultrastruct. Res. 58: $108-117$.

Reeder, R.H., T. Higashinakagawa, and O.L. Miller, Jr. 1976. The $5^{\prime}-3^{\prime}$ polarity of the Xenopus ribosomal RNA precursor molecule. Cell 8: 449-454.

Saffer, L.D. and O.L. Miller, Jr. 1986. Electron microscopic study of Saccharomyces cerevisiae rDNA chromatin replication. Mol. Cell. Biol. 6: 1148-1157.

Savino, R. and S. Gerbi. 1991. Preribosomal RNA processing in Xenopus oocytes does not include cleavage within the external transcribed spacer as an early step. Biochimie 73: 805812.

Scheer, U. and R. Benavente. 1990. Functional and dynamic aspects of the mammalian nucleolus. BioEssays 12: 14-20.

Sollner-Webb, B. and S. McKnight. 1982. Accurate transcription of cloned Xenopus ribosomal RNA genes. Nucleic Acids Res. 10: 3391-3405.

Sollner-Webb, B. and E. Mougey. 1991. News from the nucleolus: rRNA gene expression. Trends Biochem. Sci. 16: 58-62.
Sollner-Webb, B. and R.H. Reeder. 1979. The nucleotide sequence of the initiation and termination sites for rRNA transcription in Xenopus laevis. Cell 18: 485-499.

Sollner-Webb, B., K. Tyc, and J. Steitz. 1993. Ribosomal RNA processing in eukaryotes. In Ribosomal RNA: structure, evolution, processing and function in protein synthesis (ed. R. Zimmerman and A. Dahlberg). CRC Press, New York. (In press).

Spring, H., M. Trendelenburg, U. Scheer, W. Franke, and W. Herth. 1974. Structural and biochemical studies of the primary nucleus of two green algal species, Acetabularia mediterranea and Acetabularia major. Cytobiologie 10: 1-65.

Stroke, I.L. and A.M. Weiner. 1989. The 5' end of U3 snRNA can be crosslinked in vivo to the external transcribed spacer of rat ribosomal RNA. J. Mol. Biol. 210: 497-512.

Sutiphong, J., C. Matzura, and E.G. Niles. 1984. Characterization of a crude selective Pol I transcription system from Tetrahymena pyriformis. Biochemistry 23: 6319-6327.

Tower, J., S. Henderson, K. Dougherty, P. Weijksnora, and B. Sollner-Webb. 1989. An RNA polymerase I promoter located in the CHO and mouse rDNA spacers: Functional analysis, factor, and sequence requirements. Mol. Cell. Biol. 9: 15131525.

Trendelenburg, M.F. 1974. Morphology of ribosomal RNA cistrons in oocytes of the water beetle, Dytiscus marginalis L. Chromosoma 48: 119-135.

- 1981. Initiations of transcription at distinct promoter sites in spacer regions between pre-rRNA genes in oocytes of Xenopus laevis: An electron microscopic analysis. Biol. Cell 42: $1-12$.

-1982. Visualization of in vivo transcription patterns in Xenopus rDNA spacer chromatin. In Prog. Clin. Biol. Res.: Embryonic Dev., Part A: Genetic aspects /ed. M. Burgerm and R. Weber), pp. 199-210. Alan R. Liss, New York.

Trendelenburg, M.F. and J. Gurdon. 1978. Transcription of cloned Xenopus ribosomal genes visualized after injection into oocyte nuclei. Nature 276: 292-294.

Tyler, B.M. and N.H. Giles. 1985. Structure of a Neurospora RNA polymerase I promoter defined by transcription in vitro with homologous extracts. Nucleic Acids Res. 13: 43114331 .

Wilkinson, J. and B. Sollner-Webb. 1982. Transcription of Xenopus ribosomal RNA genes by RNA polymerase I in vitro. I. Biol. Chem. 257: 14375-14383.

Windle, J. and B. Sollner-Webb. 1986. Upstream domains of the frog rDNA promoter are revealed in microinjected oocytes. Mol. Cell. Biol. 6: 1228-1234. 


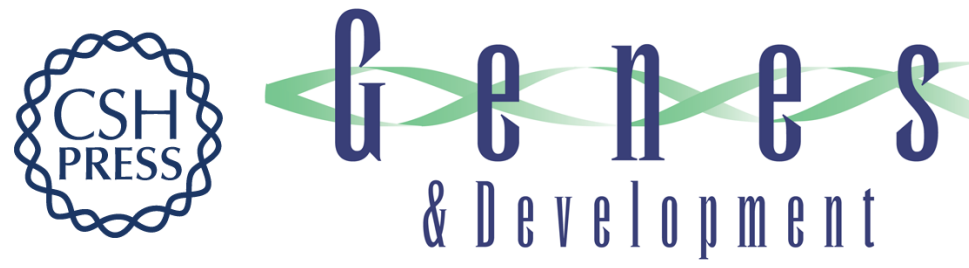

\section{The terminal balls characteristic of eukaryotic rRNA transcription units in chromatin spreads are rRNA processing complexes.}

E B Mougey, M O'Reilly, Y Osheim, et al.

Genes Dev. 1993, 7:

Access the most recent version at doi:10.1101/gad.7.8.1609

References This article cites 58 articles, 16 of which can be accessed free at:

http://genesdev.cshlp.org/content/7/8/1609.full.html\#ref-list-1

License

Email Alerting

Service

Receive free email alerts when new articles cite this article - sign up in the box at the top right corner of the article or click here.

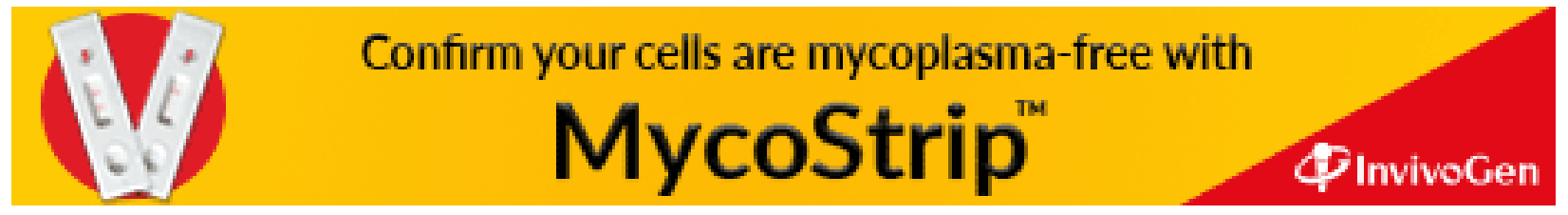

